\title{
Investigating Graduate Level Research and Statistics Courses in Schools of Education
}

\author{
Nancy L. Leech and Carolyn A. Haug \\ University of Colorado Denver, Denver, Colorado, United States
}

\section{Nancy.Leech@ucdenver.edu Carolyn.Haug@ucdenver.edu}

\begin{abstract}
Instruction in research methods, particularly statistical training, is an essential requirement for most higher education advanced-degree students. However, results from the institutional survey reported here demonstrate that many faculty in schools of education still do not require or offer a variety of research and analysis courses to provide this training. This article will explore graduate-level requirements for research methods and data analysis courses in schools of education across the United States. Two surveys, one asking questions about research methods courses and one about statistics courses, were distributed through listservs to faculty at institutions of higher education. Twenty-eight responses, representing 28 institutions, were collected for the research course survey and 19 responses, representing 19 institutions, were collected for the statistics course survey. The number of courses offered and required and the number of credit hours for them are presented for Master's, Ed.D., and Ph.D. students. From this study, it is evident that several universities do not offer or require many research methods or statistics courses for education graduate students. The authors intend that this information will assist faculty in rethinking what coursework is necessary to educate successful graduate students.
\end{abstract}

Keywords: research courses; statistics courses; requirements in doctoral programs; requirements in Master's programs

\section{Introduction}

Faculty in schools of education have questioned what research and analysis methods courses should be taught and how many research and analysis methods courses are appropriate in order to have students graduate with the ability to conduct rigorous research (Levine, 2007; Page, 2001). As used in this study, a school of education is a school, college, or department at an institution of higher education offering graduate degrees and initial and advanced educator preparation licensure programs. It is important for students to become successful researchers, as Cravens, Ulibarri, Cornelius, Royalty, and Nabergoj (2014) state, "As important as it is that students learn concrete

Material published as part of this publication, either on-line or in print, is copyrighted by the Informing Science Institute. Permission to make digital or paper copy of part or all of these works for personal or classroom use is granted without fee provided that the copies are not made or distributed for profit or commercial advantage AND that copies 1) bear this notice in full and 2) give the full citation on the first page. It is permissible to abstract these works so long as credit is given. To copy in all other cases or to republish or to post on a server or to redistribute to lists requires specific permission and payment of a fee. Contact Publisher@InformingScience.org to request redistribution permission. analytic techniques, it is even more important that they graduate with the competence to undertake independent research" (p. 242). In 2001, Page asked,

Should doctoral programs require preparation in research methods and if so, why? Should all students...gain competence in research methodology, and in one or several?...And how much of a doctoral program should be devoted to 
methodological preparation, as opposed to foundational or empirical literatures on key topics? (p. 19)

Interestingly, even though these questions were posed over a decade ago, very little research has been conducted to better understand what experiences and courses help to develop successful educational researchers (Leech, 2012).

There are few published studies investigating research and statistics courses in schools of education. For example, one study (Capraro \& Thompson, 2008) investigated required doctoral-level research courses at 21 schools or colleges of education and found that $72 \%$ required a quantitative course, $46 \%$ required a qualitative course, and $26 \%$ required neither. Similarly, Leech and Goodwin (2008) researched methods courses at 100 schools or colleges of education and found $63 \%$ required basic statistics, $54 \%$ required intermediate statistics, $62 \%$ required a quantitative research course, and $62 \%$ required a qualitative course. Other researchers have focused on specific schools and/or colleges of education or entire universities as case studies (e.g., Allen, Smyth, \& Wahlstrom, 2002; Bernauer, Semich, Klentzin, \& Holdan, 2013; Brooke, Chen, Lui, \& Valle, 2013; Harris, Freeman, \& Aerni, 2009; Kuipers, 2011; Leonard \& Fennema, 2008), yet little has been published looking across schools.

A few researchers have investigated research and statistics courses in schools and programs in different disciplines. Sonstrom, Rachal, and Mohn (2012) researched 37 North American doctoral programs in adult education and compared their course descriptions to the published Standards for Graduate Education in Adult Education (Commission of Professors of Adult Education, 2008). These researchers found $91.9 \%$ of the programs met the standard of "appropriate depth of qualitative or quantitative research methodology coursework to support dissertation research and ability to use existing literature" (Sonstrom et al., 2012, p. 156). In contrast, Ishiyama, Miles, \& Balarezo (2010) explored 122 Ph.D.-granting political science programs in the United States and their focus on teaching students to teach. Their findings reveal that there is little focus on teaching graduate students to teach quantitative methods; interestingly, qualitative or mixed methods was not mentioned. Finally, Jones (2013) examined 995 papers written between the years 1971 and 2012 on the topic of doctoral studies. From this analysis, six themes emerged: (a) teaching, (b) doctoral program design, (c) writing and research, (d) employment and career, (e) studentsupervisor relationship, and (f) the doctoral student experience. Concerning writing and research, "the discussions around writing and research focused on the increasing need for students to write well and publish, and to do so earlier with an increased emphasis on quality" (Jones, 2013, p. 89). Six sub-themes for writing and research were identified: collaborative approaches, research awareness, students' attitude toward writing, training for research and publication, pressure to publish, and research productivity.

To complicate the issue, the different programs offered through schools of education (i.e., Ph.D., Ed.D., and Master's) usually have different requirements for their methods courses (Carnegie Project on the Education Doctorate, 2009). According to the Association of American Universities (1998), having a Ph.D. indicates an ability to conduct empirical research. The Carnegie Project on the Education Doctorate (CPED) (Carnegie Project on the Education Doctorate, 2015) was developed to distinguish between Ph.D. degrees and Ed.D degrees in schools of education mainly in the US, currently also with two participating universities in Canada, with the focus on how Ed.D. degrees prepare students to develop professional knowledge by integrating practical and research knowledge (Carnegie Project on the Education Doctorate, 2009). The main difference between the Ed.D. and Ph.D. degree is that the Ed.D. program stresses practical and applied research that investigates problems of practice and the Ph.D. program has a broader focus for research; yet, each of these doctoral programs must prepare students to conduct research. 
Regardless of the program, it is important for students to learn how to conduct qualitative, quantitative, and mixed methods research (Tashakkori \& Creswell, 2008). According to Henson, Hull, and Williams (2010), "Newly minted education researchers should be able to read and critically evaluate research findings from a wide range of methods while being expert in a specific methodological orientation" (p. 229). Yet, "a serious discussion of how to prepare scholars in research methodology is relatively uncharted" (Tashakkori \& Creswell, 2008, p. 291). Furthermore, there is little information guiding what students should know and be able to do in regard to research, and debate over how much of a graduate program should be devoted to methodological preparation as opposed to foundational concepts in focus areas of study.

Ensuring that the advanced degree meets the needs of stakeholders is a worldwide concern (Carnegie Project on the Education Doctorate, 2015; Higher Education Funding Councils, 2003). Because globalization heavily impacts higher education and moves it toward increased international involvement (Altbach \& Knight, 2007), the field of advanced study in education is in need of studies of how prepared all students are, not just those from our own classes and programs. Higher education must prepare students for global work regardless of where they went to school. However, few studies exist to meet these needs. In education, Allen, Smyth \& Wahlstrom (2002) documented the rationale for significant revision to a Canadian Ph.D. program, decisions based largely on the recognition that the traditional Ph.D. curriculum was not meeting the needs of the broad audience of stakeholders.

Other professional areas, such as nursing, political science, and the arts and sciences, have posed similar ideas. For example, after finding very little research outside the United States on quality nursing programs, Kim, McKenna, \& Ketefian (2006) investigated and developed guidelines for "quality criteria, standards, and indicators for doctoral programs in nursing that may be used worldwide" (p. 477). In the field of political science, the quality of doctoral student preparedness by research universities in the United States was found to be lacking in a variety of areas (Schwartz-Shea, 2003). A survey of doctoral students in the arts and sciences suggested that the curriculum needed revision to prepare them for their jobs (Golde \& Dore, 2001). The current study investigates the commonality across research universities in the United States in the area of research methods preparation for advanced education students, and calls for additional studies in other settings. We anticipate that the current survey research study can serve as an initial exploration of offerings and requirements in schools of education, and that it will allow for identification of other research questions (e.g., why are certain courses required/not required? Why are certain courses offered/not offered? What are the challenges to providing graduate education students with more comprehensive research and analysis training?), which can serve as the basis for further research.

\section{Conceptual Framework}

This study utilized Leech's (2012) model for understanding how to educate knowledgeable and skilled researchers as a conceptual framework. Leech's (2012) model builds on three extant theories/studies (Bozeman, Dietz, \& Gaughan, 2001; Levine, 2007; Lovitts, 2005). Bozeman, Dietz, and Gaughan (2001) developed the Theory of Scientific and Technical (S\&T) Human Capital, which encapsulates human capital (i.e., cognitive skills, knowledge, craft skills) and social/research project capital (i.e., research projects). Human capital includes a person's cognitive skills, craft skills, and knowledge. Social capital is "the sum of resources, actual or virtual, that accrue to an individual or group by virtue of possessing a durable network of more or less institutionalized relationships of mutual acquaintance and recognition" (Bourdieu \& Wacquant, 1992, p. 119). Leech (2012) adapted these ideas into the following areas: cognitive skills, amount of knowledge, and social capital (measured by the research projects a researcher is involved in). The model includes qualitative, quantitative, and mixed methods projects as well as indicators of the 
level of participation, from low participation (e.g., being fourth author on a project) to high participation (e.g., being first author on a project). Based on the adapted model, a novice researcher would have low cognitive skills, low knowledge, and little social capital. In comparison, a skilled and knowledgeable researcher would have high cognitive skills and knowledge, and broad social capital.

Levine's (2007) study researched three areas of schools of education including the program (i.e., purpose, admissions, graduation and degree standards, finances), the curriculum (i.e., how well it matches the purpose and goals of the program, how often the students have other experiences outside of the classroom, as well as assessment), and the faculty (i.e., productivity, expert teachers, and research quality) to identify what aspects of a program are needed to graduate successful researchers. A successful researcher is defined as a researcher who can effectively participate in "the preparation of grant proposals and the writing and presentation of research papers" (p. 25). From this investigation, Levine identified nine aspects that are associated with successful researchers: (a) purpose of program, (b) curriculum coherence, (c) curriculum balance, (d) faculty, (e) admissions, (f) graduation and degree standards, (g) research, (h) finances, and (i) assessment. Students who attended programs that included all nine points tended to graduate researchers that are more successful. According to Levine (2007) an:

exemplary program is one that substantially meets all nine criteria. A strong program is one that substantially satisfies most of the criteria. An inadequate program is defined as one that fails to achieve most of the criteria or has a fatal flaw, such as having faculty who do not publish. (p. 16)

Finally, Lovitts (2005) developed a model to better understand how to develop skilled and knowledgeable researchers. The model outlines factors that "produce outstanding research and scholarship" (p. 139). In the model there are three interacting main areas: the macro environment which includes the culture of the discipline, the microenvironment which includes the location of school and the advisor, and individual resources which includes intelligence and motivation). According to Lovitts, if any of these areas is deficient the probability decreases of a student producing a quality dissertation and becoming a successful researcher.

Leech (2012) took these three theories/studies and developed a new model that infuses aspects of all three extant theories/studies. Figure 1 depicts the new model from Leech (2012). This model incorporates the macroenvironment (i.e., the culture of the graduate education and the culture of the discipline), the microenvironment (i.e., advisor, mentoring, peers and other faculty, department, curriculum, instruction, assessment, standards, and location), and individual resources (i.e., intelligence, motivation, knowledge, personality, and thinking styles) These multiple facets combine to create a skilled and knowledgeable researcher with the Program (i.e., the curriculum) being important to this success. 


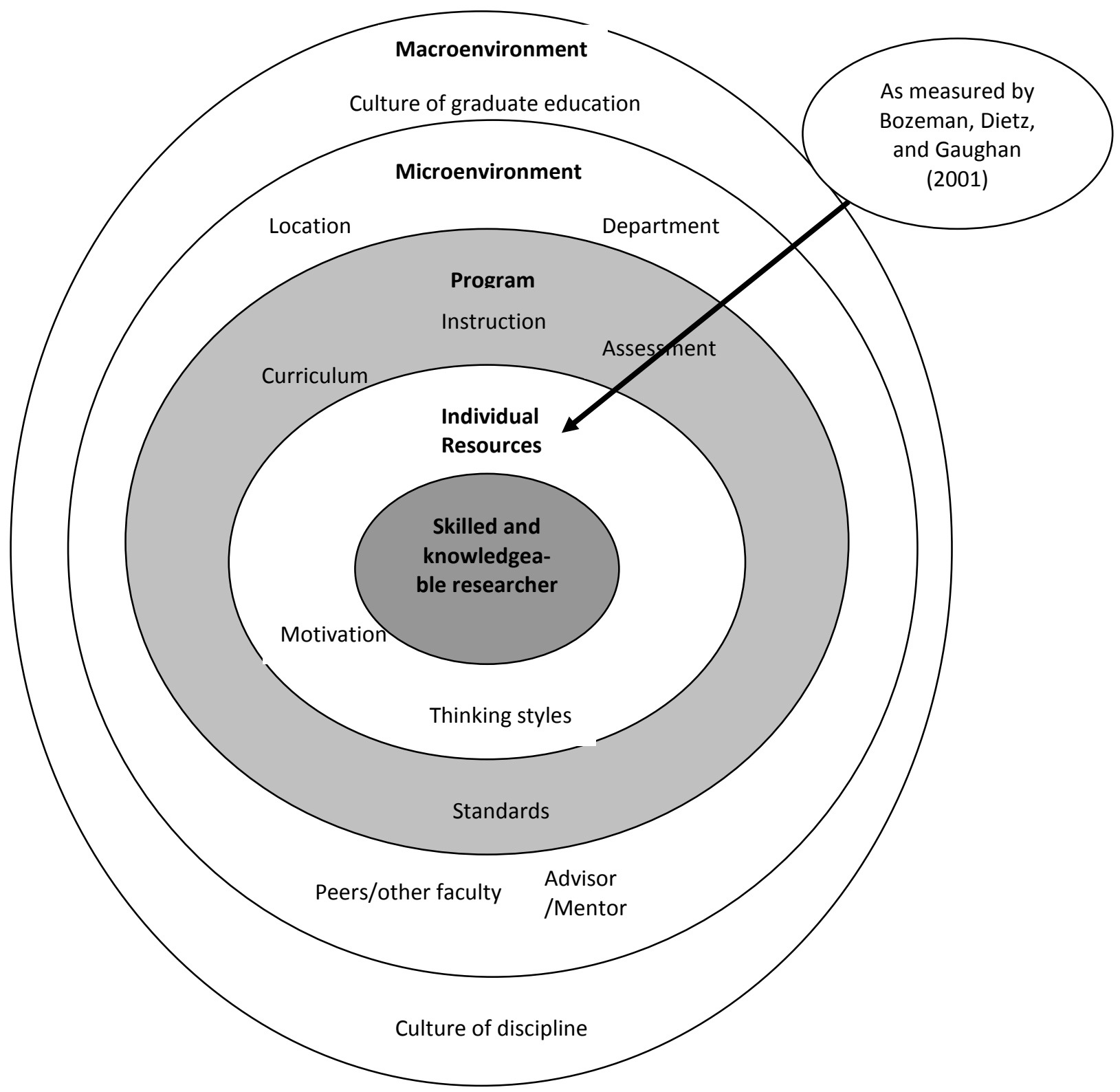

Figure 1. Leech's (2012) model for understanding doctoral student success.

The purpose of this study was to build on Leech and Goodwin's (2008) study to increase understanding of current inquiry course requirements in Master's and doctoral programs in schools and colleges of education around the country and explore the balance between qualitative and quantitative inquiry course requirements. This study will answer the following research questions: (a) What type of research and statistics courses are being offered in Master's, Ed.D., and Ph.D. programs in the United States?, and (b) What type of research and statistics courses are being required by Master's, Ed.D., and Ph.D. programs in the United States? 


\section{Methods}

This study was an exploratory quantitative study. The survey used in Leech and Goodwin's (2008) study was updated and adapted for online dissemination. Questions focused on the type of degree(s) offered, the number of full time students admitted to and completing the program, the types of courses offered and required for each level of student (i.e., Master's, Ed.D., and Ph.D.), whether there were differing expectations in these courses for each level of student, and whether there were changes being contemplated for any of the programs. The research and statistics surveys were tailored to the discipline of education at the graduate level and are presented in the Appendix. The institutional research board's approval at the authors' institution gave approval for the conduct of this study.

\section{Participants and Procedure}

A convenience sample of participants was identified through the three listservs: (a) the listserv for the American Educational Research Association's (AERA) Special Interest Group (SIG) Professors of Educational Research, (b) the listserv for the AERA's SIG Educational Statisticians and (3) the listserv for the AERA's SIG Mixed Methods Research. A posting was available on the listservs explaining the study's purpose, asking whether the recipient taught research or statistics courses in a school of education university setting or was someone who knew about the program's required and elective courses, explaining how the participation was voluntary, outlining the benefits and risks of participating in the study, and requesting participation in the study. The survey asked for the name, position, and the institution for which they were reporting so that only one person reported on the same institution. The respondents included assistant professors, associate professors, full professors, and chairs of departments. The posting provided two links: one for a survey regarding statistics courses and one for a survey asking about research courses. By completing the survey, the participants were indicating their consent.

The online survey was administered and managed using REDCap (Research Electronic Data Capture), an electronic data capture tool (Harris et al., 2009), hosted at the University of Colorado Denver. Twenty-eight responses representing 28 different institutions were collected for the research course survey and 19 responses representing 19 different institutions were collected for the statistics course survey.

\section{Analysis}

The unit of analysis for this study was the institution. It was not possible to determine a response rate because we cannot quantify the universe of schools of education represented in the three AERA SIG listservs. Multiple SIG members might belong to the same school of education, negating our ability to count institutions by counting SIG members. For each school of education, only one response was admitted for analysis. We did not receive more than one response per institution.

Researchers used descriptive statistics to analyze results from the surveys. Data were downloaded from REDCap to SPSS version 22. After the data were downloaded into SPSS all identifiers were removed.

\section{Results}

\section{The Research Survey}

Of the participants who responded to the research methods course survey, 15 (54\%) offered an M.A., 25 (89\%) offered a M.S., and 13 (46\%) offered an Ed.D., and 18 (64\%) offered a Ph.D. For 
these participants, the number of students admitted in these programs ranged from 6 to $2000(M=$ 204.79 , Median $=30.00, S D=471.18)$ and the number of students who completed the program ranged from 0 to $2000(M=185.18$, Median $=22.00, S D=479.67)$.

Twenty-five percent of the programs reported having differing expectations for Master's, Ed.D., and Ph.D. students in the research courses. As for specialty research courses that are offered, the following were listed by program: (a) ethnography, evaluation, needs assessment, case study, and single case design; (b) paradigms of research; (c) qualitative case study, single subject/case, measurement, survey research, self-study, program evaluation; and (d) survey research.

Table 1 presents the number and percent of respondents that indicated that the research course was required or offered as an elective. The table also includes the range, mean, and standard deviations for the number of credits for the research methods courses. Overall, more than half of the programs required and provided elective research courses for Master's students (57\%). Interestingly, most of the Master's level programs required basic research methods courses (54\%) with very few Master's programs requiring qualitative research methods courses $(7 \%)$ or quantitative research courses (7\%). None of the Master's programs required advanced courses in qualitative or quantitative research methods, although $7 \%$ provide an advanced qualitative course and $11 \%$ provide an advanced quantitative course as electives. Regarding mixed methods courses, none of the programs required a mixed methods course with only one program offering it as an elective. None of the Master's level programs offered other specialty courses (e.g., survey methods, ethnography). The number of credits for all Master's courses ranged from 3-6 credits. One course in basic research design, with optional additional courses, seems to be the requirement in about half of these programs. However, the other approximately half of these Master's programs do not have any research course requirements.

Less than half (43\%) of the Ed.D. programs reported having research methods courses available for their students. Of these courses, $36 \%$ required a basic research methods course, with the number of required credits ranging from $3-9$. Qualitative courses were required by $36 \%$ of the programs, with required credits ranging from $3-6$, and $32 \%$ required a quantitative course. None of the Ed.D. programs required advanced qualitative or quantitative courses. A required mixed methods course was rare ( $7 \%$ of the programs), as was an elective mixed methods course $(7 \%$ of the programs). No institutions reported any specialty courses as being available for Ed.D. students. This might be due to Ed.D. cohort models where the students do not have an option to take an elective course.

For Ph.D. students, 25\% of the programs provide research methods courses for their students. Only $14 \%$ require a basic research methods course with required credits ranging from $3-4$. A fourth of the programs (25\%) reported requiring a qualitative research methods course, and only $7 \%$ require an advanced qualitative research methods course. Additionally, only $7 \%$ require a quantitative research methods course, with only $7 \%$ of the Ph.D. programs offering an advanced quantitative research methods course. Only $7 \%$ of the programs require a mixed methods course, with $11 \%$ offering the course as an elective. Almost all course credits ranged from $3-4$. The paucity of research methods requirements for Ph.D. students is noteworthy because of their need to conduct original research to complete the degree and succeed in certain careers. 


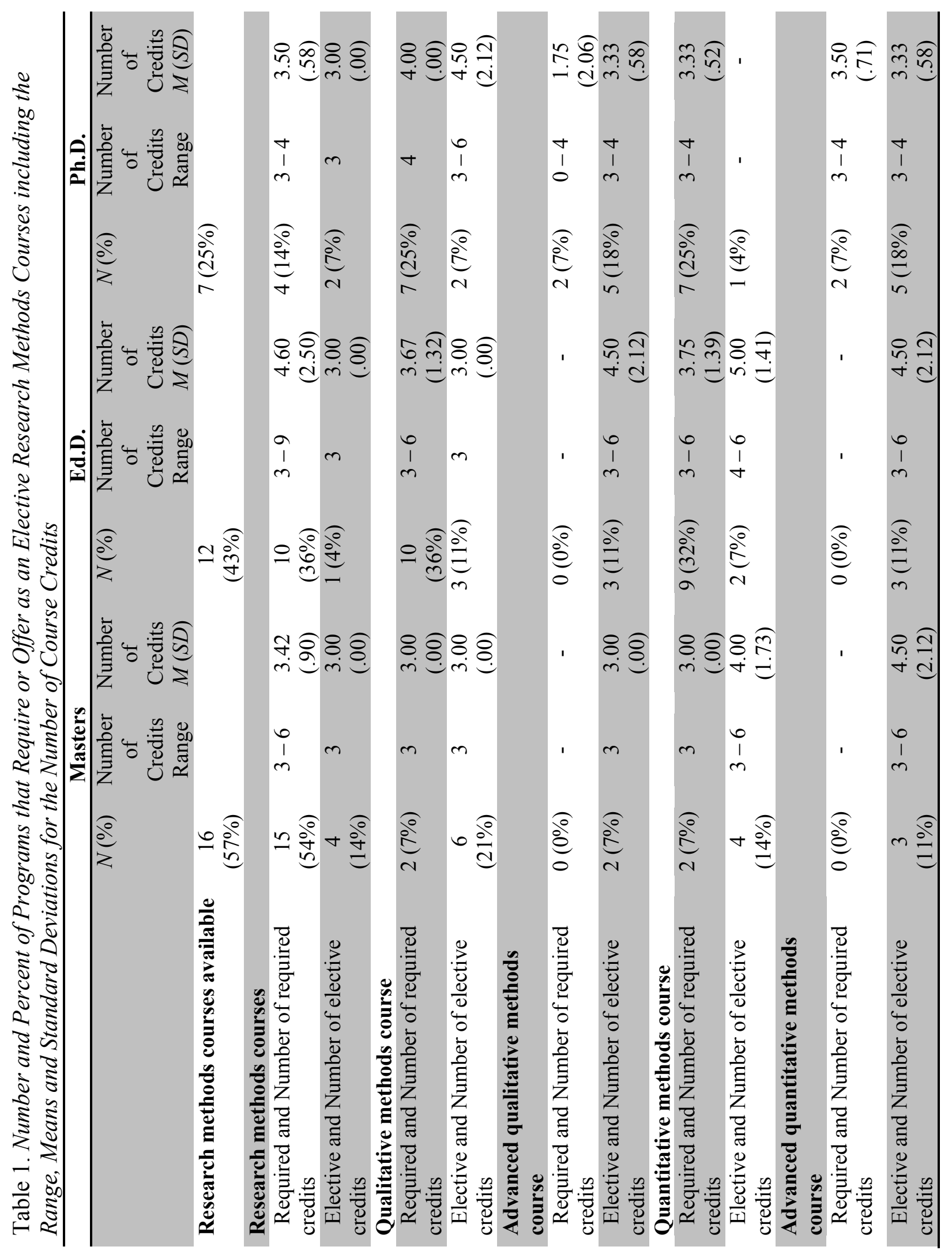




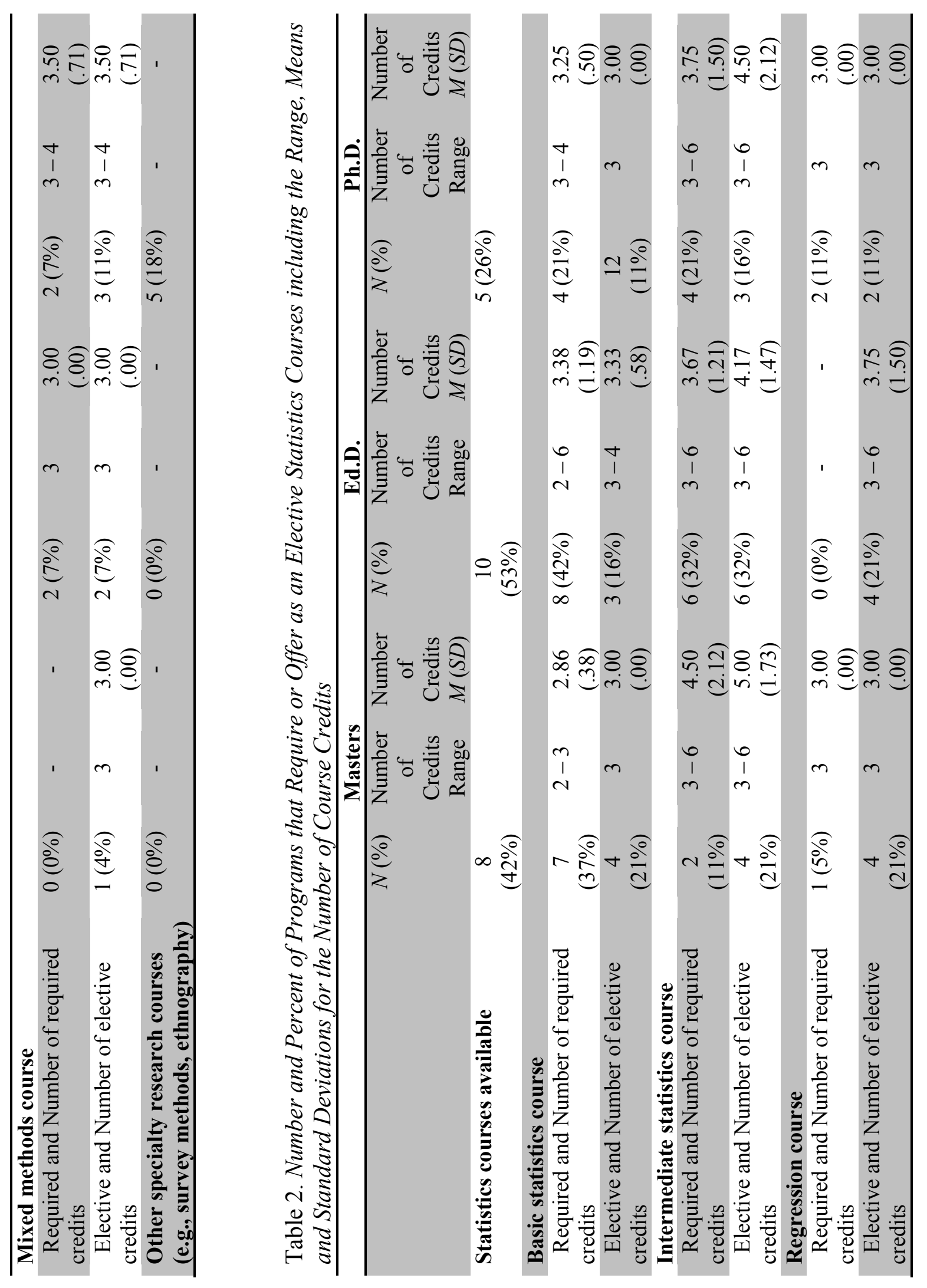




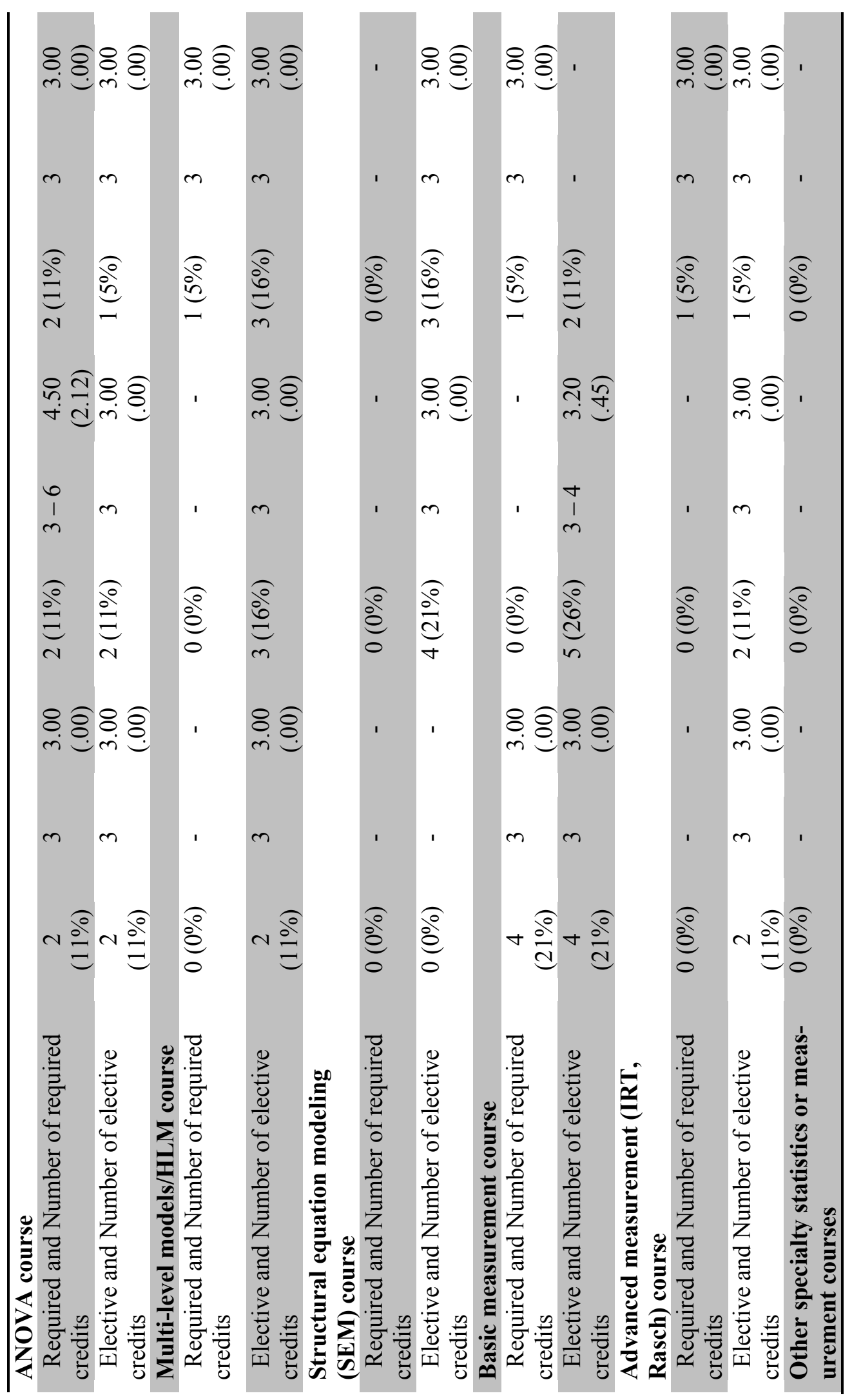




\section{The Statistics Survey}

For the participants who responded to the statistics course survey, 11 (58\%) offered an M.A., 15 (79\%) offered an M.S., 7 (37\%) offered an Ed.D., and 11 (58\%) offered a Ph.D. For these participants, the number of students currently enrolled in these programs ranged from 6 to $2000(M=$ 254.20, Median $=49.00, S D=616.26)$ and the number of students who completed the program ranged from 0 to $2000(M=261.22$, Median $=30.00, S D=654.86)$. Table 2 presents the number and percent of respondents that indicated that the statistics course was required or offered as an elective. The table also includes the range, mean, and standard deviations for the number of credits for the statistics courses. Concerning having differing expectations in courses for Master's, Ed.D., and Ph.D. students, 26\% responded that there were differences. None of the programs reported contemplating making changes to course requirements.

Forty-two percent of the Master's programs reported having statistics courses available for their students. Over a third (37\%) of the Master's programs required a basic statistics course, with 21\% offering it as an elective. Interestingly, the range of credits for required basic statistics courses ranged from $2-3$. Only $11 \%$ of the programs required intermediate statistics course with $21 \%$ offering it as an elective. Only one program required a course in regression with $21 \%$ offering it as an elective. Eleven percent required an ANOVA course for Master's level students. None of the Master's level programs required a course in multi-level modeling/hierarchical linear modeling (HLM) or structural equation modeling (SEM). Only $21 \%$ of the programs required a basic measurement course and none of the programs required an advanced measurement (e.g., item response theory, Rasch modeling) course. None of the Master's level programs offered any specialty statistics or measurement courses.

For the Ed.D. students, 53\% of the programs reported having statistics courses available. Fortytwo percent of the programs required a basic statistics course for their Ed.D. students, with course credits ranging from $2-6$, and $16 \%$ of the programs offering it as an elective. About one-third $(32 \%)$ of the programs required an intermediate statistics course and the same number of programs offered this course as an elective. Only $11 \%$ of the programs required an ANOVA course. None of the Ed.D. programs required courses on regression, multi-level modeling/HLM, SEM, basic measurement, advanced measurement, or other specialty courses. Most of the course credits for these courses ranged from $3-6$.

Only $21 \%$ of the Ph.D. programs required a basic statistics course, with credits ranging from 3 4 , and $11 \%$ offered it as an elective. Less than a fourth $(21 \%)$ of the Ph.D. programs required an intermediate statistics course. Only $11 \%$ required a regression course or a course on ANOVA. Interestingly, only $5 \%$ of the programs required a multi-level modeling/HLM, basic measurement, or advanced measurement courses, and none required courses on SEM or other specialty statistics or measurement courses.

\section{Discussion}

Using the model for understanding doctoral student success (Leech, 2012) introduced earlier, this study focuses on the program component within the microenvironment in an effort to better describe the potential to produce skilled and knowledgeable researchers. According to this model, the curriculum clearly is a key component to graduate student success. To be successful, doctoral students world-wide must be prepared to conduct empirical research (Association of American Universities, 1998; Carnegie Project on the Education Doctorate, 2009; Cravens et al., 2014; Higher Education Funding Councils, 2003; Jones, 2013; Sonstrom et al., 2012) leading to the conclusion that the doctoral curriculum, both for Ph.D. and Ed.D. programs, must include high quality research design and analysis courses. We extend these arguments to include advanced education Master's degree programs because they also prepare education leaders who must un- 
derstand and apply research and measurement issues and acknowledge that there might be less uniformity in expectations in these programs, which could contribute to variability in Master's program requirements and offerings.

Interestingly, the results from the extant literature, regardless of country, tend to agree that more methods and statistics courses are needed in higher education to educate skilled researchers (e.g., Allen et al., 2002; Capraro \& Thompson, 2008; Kim, McKenna, \& Ketefian, 2006; Leech \& Goodwin, 2008; Tashakkori \& Creswell, 2008). This study contributes to the limited literature regarding the research methods and statistics courses offered by and required by graduate education programs at the masters, Ed.D., and Ph.D. levels in the United States, and adds to the broader international and interdisciplinary knowledge bases.

Not only do students need to be prepared to design and conduct studies utilizing quantitative data, they also need to be prepared to conduct studies with qualitative data and be able to combine both types of data in a mixed methods design (Henson et al, 2010; Tashakkori \& Creswell, 2008). Despite the broad agreement about the necessity of graduate student preparation for research, available evidence indicates that required program coursework is inadequate. Results from the current study indicated there were low percentages of doctoral programs requiring research methods, basic qualitative and basic quantitative courses, and a near absence of programs requiring mixed methods or advanced courses. The dearth of requirements for qualitative and mixed methods courses is problematic, as is the spottiness of required quantitative and research design courses, for producing skilled and knowledgeable researchers according to Leech's (2012) model.

The Master's program requirement for research methods courses may partially explain the low percentage of doctoral programs requiring research courses: the doctoral programs may operate on an assumption that all entering doctoral students have taken a research methods course in a Master's program. However, these results indicate this is a faulty assumption because, although approximately half of the Master's programs require a research methods course, about half of them do not; additionally, courses taken in a Master's program completed possibly many years earlier may not be adequate to provide a solid basis for a doctoral student. One could make a similar argument about the basic measurement course, which is required in about one-fifth of Master's programs and only one doctoral program.

Although several institutions offer additional elective courses in research methods, qualitative methods, advanced qualitative methods, quantitative methods, advanced quantitative methods, and mixed methods, the percentage offering each type of these courses varies greatly and no one category of these electives is offered commonly, i.e., no one topic is offered consistently across programs. Where offered as electives, they can only be effective in developing high quality researchers to the extent that students are able to fit the elective courses into their schedules, motivated to take the course, and willing to pay for the additional credit hours required.

The most commonly required quantitative courses are basic statistics followed by intermediate statistics. Specialty statistics courses such as regression, ANOVA, multilevel modeling, and structured equation modeling are rarely available to doctoral students even as electives. Basic measurement courses were not commonly required, although their availability as an elective was somewhat more frequent.

This study shows that less than one-quarter of Ph.D. programs from our United States based sample require an intermediate statistics course, the level at which inferential statistics is thoroughly addressed, which begs a question about how prepared the newly-minted Ph.D. students will be to become the researchers we intend. A similar situation exists for students in the Ed.D. programs, where less than one-third require intermediate statistics. How prepared will the new Ed.D. students be to conduct and consume applied research studies? A new doctoral student coming from a Master's program that required courses in research methods, basic statistics, and basic measure- 
ment and entering a doctoral program that requires intermediate statistics and a basic qualitative methods course and offers additional electives should provide a sound foundation that enables the doctoral student to be a successful researcher. However, this ideal situation does not apply to all students and programs: not all Master's programs require these courses and not all doctoral program require even intermediate statistics or basic qualitative methods, nor do they all offer advanced methods courses.

Limitations to the current study include the nature of the sample, size of the sample, and representativeness of the sample. This study is based on a voluntary, convenience sample of institutional respondents to the two surveys administered The sample is drawn from the United States and findings from this study may have less import in countries where there is more uniformity and centralized control over higher education. We are unable to calculate a response rate for the surveys because of the inability to quantify the institutions represented by listserv members receiving them. Further research is necessary to determine how representative these results are of all doctoral-granting institutions in the country.

With the increase in globalization (Altbach \& Knight, 2007), it is imperative that faculty in higher education focus on preparing students for a wide range of positions that will allow them to impact innovation world-wide. Examples of how to approach the issue of reviewing and revising curricular requirements in advanced education programs exist, though they are limited, in other countries and profession fields. The Canadian example of consulting stakeholders to solicit feedback about advantageous program and curricular revisions (Allen et al., 2002) may be a valuable initial step. Ultimately, the education field may look to the program quality guidelines developed for advanced nursing degrees (Kim et al., 2006) or graduate curricula in other fields (Jones, 2013; Sonstrom et al., 2012) as models for similar quality standards in advanced education degrees.

Our requirements speak to our values. When faculty and administrators negotiate degree requirements, they make difficult decisions with regard to cost, length of time, and content areas. However, it seems that graduating students from advanced education programs without an assurance of an adequate research toolkit may be a disservice to them and to the field. Results from the current study should encourage faculty world-wide to carefully review current program requirements and consider the extent to which they assure all education graduate students receive a solid and adequate foundation to become successful researchers and leaders, an exercise that none of the programs reported contemplating at this time.

\section{References}

Allen, C. M., Smyth, E. M., \& Wahlstrom, M. (2002). Responding to the field and to the academy: Ontario's evolving PhD. Higher Education Research \& Development, 21(2), 203-214. doi: 10.1080/07294360220144114

Altbach, P. G., \& Knight, J. (2007). The internationalization of higher education: Motivations and realities. Journal of Studies in International Education, 11, 290-305. doi: 10.1177/1028315307303542

Association of American Universities. (1998). Committee on graduate education report and recommendations. Washington DC: Author.

Bernauer, J. A., Semich, G., Klentzin, J. C., \& Holdan, E. G. (2013). Themes of tension surrounding research methodologies education in an accelerated, cohort-based doctoral program. International Journal of Doctoral Studies, 8, 173-193. Retrieved from http://ijds.org/Volume8/IJDSv8p173193Bernauer0397.pdf

Bourdieu, P., \& Wacquant, L. J. D. (1992). An invitation to reflexive sociology. Chicago, IL: University of Chicago Press. 
Investigating Graduate Level Research and Statistics Courses

Bozeman, B., Dietz, J. S., \& Gaughan, M. (2001). Scientific and technical human capital: An alternative model for research evaluation. International Journal of Technology Management, 22(7-8), 716-740. doi:10.1504/IJTM.2001.002988

Brooke, G., Chen, F., Lui, A., \& Valle, C. (2013). Using a mixed-methods survey of alumni for program evaluation and improvement: A case study from a doctoral program in education. The Researcher, 25(1), 21-33.

Capraro, R. M., \& Thompson, B. (2008). The educational researcher defined: What will future researchers be trained to do? Journal of Educational Research, 101, 247-253.

Carnegie Project of the Education Doctorate. (2009). Working principles for the professional practice doctorate in education. College Park, MD, Author.

Carnegie Project on the Education Doctorate. (2015). The Carnegie Project on the Education Doctorate is a national effort aimed at strengthening the education doctorate Ed.D. Retrieved from http://cpedinitiative.org

Commission of Professors of Adult Education. (2008, November). Standards for graduate programs in adult education. Retrieved from http://cpae.memberclicks.net/assets/documents/CPAE\%20Grad\%20Standards\%202008.pdf

Cravens, A. E., Ulibarri, N., Cornelius, M., Royalty, A., \& Nabergoj, A. S. (2014). Reflecting, iterating, and tolerating ambiguity: Highlighting the creative process of scientific and scholarly research for doctoral education. International Journal of Doctoral Studies, 9,229-247. Retrieved from http://ijds.org/Volume9/IJDSv9p229-247Cravens0637.pdf

Golde, C. M., \& Dore, T. M. (2001). At cross purposes: What the experiences of doctoral students reveal about doctoral education (www.Ph.D.-survey.org). Philadelphia, PA: A report prepared for The Pew Charitable Trusts.

Harris, J. B., Freeman, T. L., \& Aerni, P. W. (2009). On becoming educational researchers: The importance of cogenerative mentoring. Mentoring \& Tutoring: Partnership in Learning, 17, 23-39.

Henson, R. K., Hull, D. M., \& Williams, C. S. (2010). Methodology in our education research culture: Toward a stronger collective quantitative proficiency. Educational Research, 39, 229-240. doi: 10.3102/0013189X10365102

Higher Education Funding Councils. (2003). Improving standards in postgraduate research degree programmes: Informal consultation. Retrieved from http://www.hefce.ac.uk/pubs/hefce/2003/03 01.htm

Ishiyama, J., Miles, T., \& Balarezo, C. (2010). Training the next generation of teaching professors: A comparative study of Ph.D. programs in political science. PS: Political Science and Politics, 43(3), 515522. doi: $10.1017 / \mathrm{S} 1049096510000752$

Jones, M. (2013). Issues in doctoral studies - Forty years of journal discussion: Where have we been and where are we going? International Journal of Doctoral Studies, 8, 83-104. Retrieved from http://ijds.org/Volume8/IJDSv8p083-104JonesFT129.pdf

Kim, M. J., McKenna, H. P., \& Ketefian, S. (2006). Global quality criteria, standards, and indicators for doctoral programs in nursing: Literature review and guideline development. International Journal of Nursing Studies, 43, 477-489.

Kuipers, J. L. (2011). PhD and EdD degrees for mid-career professionals: Fielding graduate university. New Directions for Adult and Continuing Education, 129, 63-73. doi: 10.1002/ace.401

Leech, N. L. (2012). Educating knowledgeable and skilled researchers in doctoral programs in schools of education: A new model. International Journal of Doctoral Studies, 7, 19-37. Retrieved from http://ijds.org/Volume7/IJDSv7p019-037Leech325.pdf

Leech, N. L., \& Goodwin, L. D. (2008). Building a methodological foundation: Doctoral-level methods courses in colleges of education. Research in the Schools, 15, 1-8. 
Leonard, M. J., \& Fennema, E. (2008). The Wisconsin-Spencer doctoral research program: An evaluation. Teachers College Record, 110, 1379-1396.

Levine, A. (2007). Educating researchers. Washington, DC: The Education Schools Project.

Lovitts, B. E. (2005). Being a good course-taker is not enough: A theoretical perspective on the transition to independent research. Studies in Higher Education, 30(2), 137-154. doi:10.1080/03075070500043093

Page, R. N. (2001). Reshaping graduate preparation in educational research methods: One school's experience. Educational Researcher, 30(5), 19-25.

Schwartz-Shea, P. (2003, July). Is this the curriculum we want? Doctoral requirements and offerings in methods and methodology. PS: Political Science \& Politics. Retrieved from http://apsanet3b.inetu.net/imgtest/ThisCurriculumWeWant-Schwartz-Shea.pdf

Sonstrom, W. J., Rachal, J. R., \& Mohn, R. S. (2012). The commission of professors of adult education 2008 standards as evidenced in the curricula of doctoral education in North America. Adult Education Quarterly, 63(2), 147-164. doi: 10.1177/0741713612447855

Tashakkori, A., \& Creswell, J. W. (2008) Editorial: Envisioning the future stewards of the socialbehavioral research enterprise. Journal of Mixed Methods Research, 2, 291 - 295. doi: $10.1177 / 1558689808322946$ 


\section{Appendix}

Questions Included in the Survey for Teaching Statistics and Measurement Courses What type of degree(s) are students in these classes earning? (select all that apply)
$\square$ M.A.
$\square$ M.S. $\square$ Ph.D.
$\square$ Ed.D.

Number of full time M.A./M.S./Ph.D./Ed.D. students admitted in 2012 (include summer 2011, fall 2011, and spring 2012)

Number of M.A./M.S./Ph.D./Ed.D. students who completed the program in 2011 (include summer 2010, fall 2010, and spring 2011)

\section{Courses}

Please indicate the number of credits in each area that students are required to take. If the course is an elective, provide the typical number of credits students take.

\begin{tabular}{|c|c|c|c|c|c|c|c|c|}
\hline & 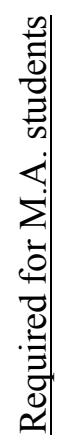 & 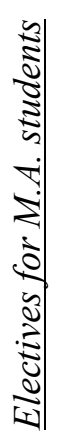 & 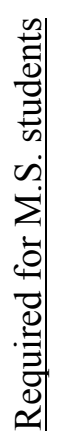 & 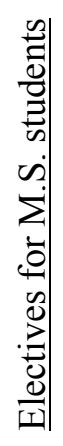 & 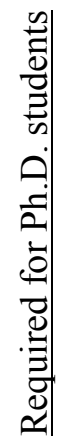 & 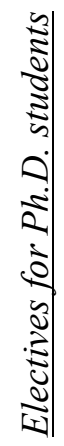 & 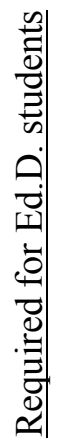 &  \\
\hline \multicolumn{9}{|l|}{ Basic statistics $\left(t, r, \chi^{2}\right.$, etc. $)$} \\
\hline \multicolumn{9}{|l|}{$\begin{array}{l}\text { Intermediate statistics (ANOVA, regression, } \\
\text { etc.) }\end{array}$} \\
\hline \multicolumn{9}{|l|}{ Regression } \\
\hline \multicolumn{9}{|l|}{ Analysis of Variance } \\
\hline \multicolumn{9}{|l|}{ Multi-level models/HLM } \\
\hline \multicolumn{9}{|l|}{ Structural Equation Modeling } \\
\hline \multicolumn{9}{|l|}{ Basic Measurement } \\
\hline \multicolumn{9}{|l|}{ Advanced Measurement (IRT, Rasch) } \\
\hline \multicolumn{9}{|l|}{$\begin{array}{l}\text { Other specialty statistics or measurement } \\
\text { courses (e.g., survey methods, advanced } \\
\text { measurement) - please specify }\end{array}$} \\
\hline Other - please specify & & & & & & & & \\
\hline
\end{tabular}

\section{Differentiation}

Are there differing expectations for master's, Ed.D., and Ph.D. students in these courses? YES NO

If you answered yes, how are the courses or the expectations within the courses different?

\section{Changes in the Program}

Are you currently contemplating making changes to your Ph.D. statistics course requirements? If so, what are they?

Please tell us about yourself and your institution

Name of person completing questionnaire:

Position of person completing questionnaire:

Name of institution: 
Questions Included in the Survey for Teaching Research Courses in

What type of degree(s) are students in these classes earning? (select all that apply)
$\square$ M.A.
$\square$ M.S. $\square$ Ph.D.
$\square$ Ed.D.

Number of full time M.A./M.S./Ph.D./Ed.D. students admitted in 2012 (include summer 2011, fall 2011, and spring 2012)

Number of M.A./M.S./Ph.D./Ed.D. students who completed the program in 2011 (include summer 2010, fall 2010, and spring 2011)

\section{Courses}

Please indicate the number of credits in each area that students are required to take. If the course is an elective, provide the typical number of credits students take.

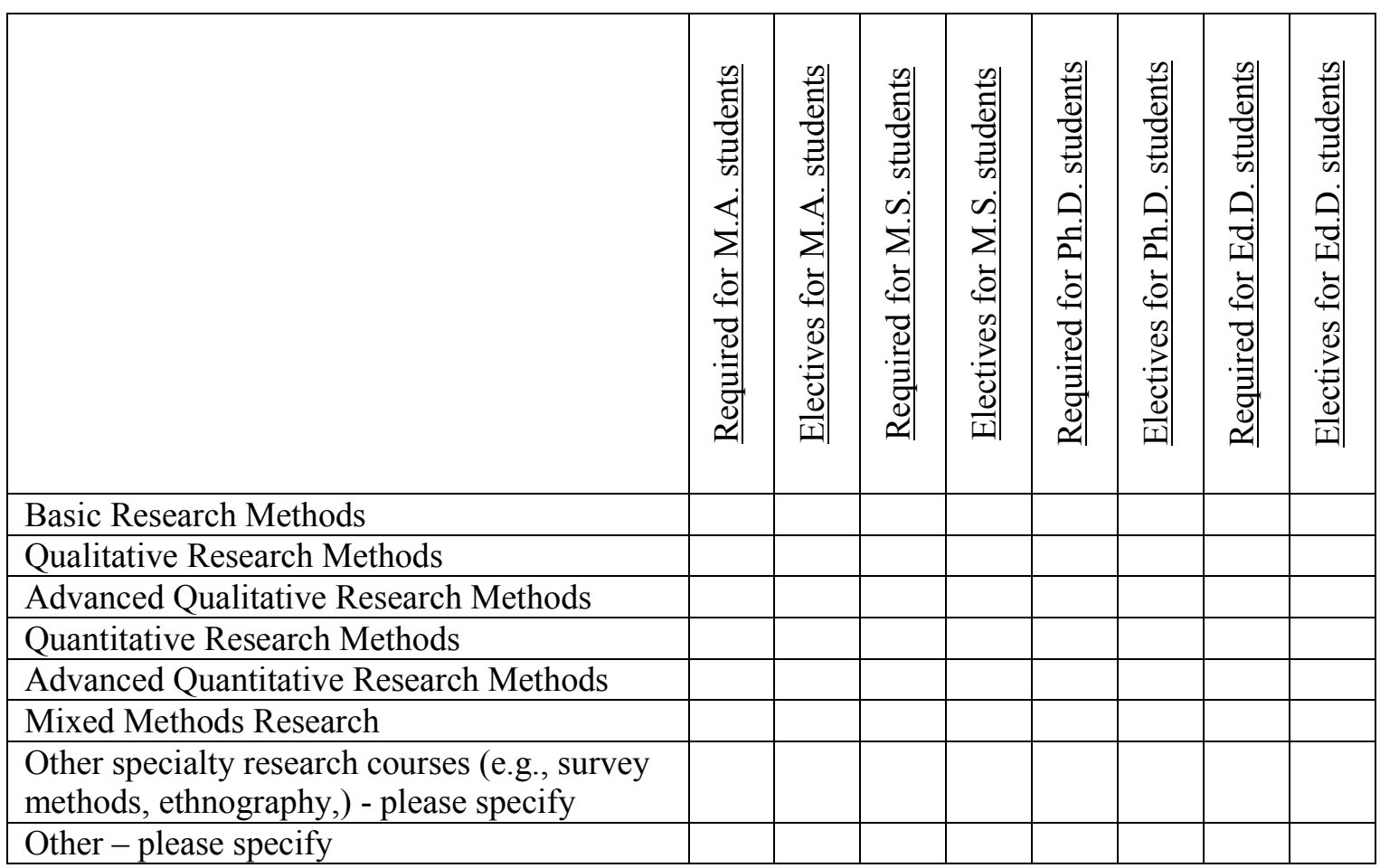

\section{Differentiation}

Are there differing expectations for master's, Ed.D., and Ph.D. students in these courses?

YES NO

If you answered yes, how are the courses or the expectations within the courses different?

\section{Changes in the Program}

Are you currently contemplating making changes to your Ph.D. research course requirements? If so, what are they?

\section{Please tell us about yourself and your institution}

Name of person completing questionnaire:

Position of person completing questionnaire:

Name of institution: 


\section{Biographies}

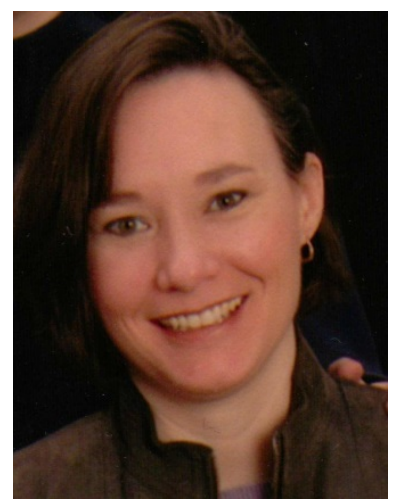

Nancy L. Leech, Ph.D. is a professor at the University of Colorado Denver. Dr. Leech is currently teaching master's and Ph.D. level courses in research, statistics, and measurement. Her area of research is promoting new developments and better understandings in applied qualitative, quantitative, and mixed methodologies. To date, she has published more than 70 articles in refereed journals, and is co-author of three books; SPSS for Basic Statistics: Use and Interpretation, SPSS for Intermediate Statistics: Use and Interpretation, and Research Methods in Applied Settings: An Integrated Approach to Design and Analysis, all published by Taylor and Francis. Dr. Leech has made more than 85 presentations at regional, national, and international conferences.

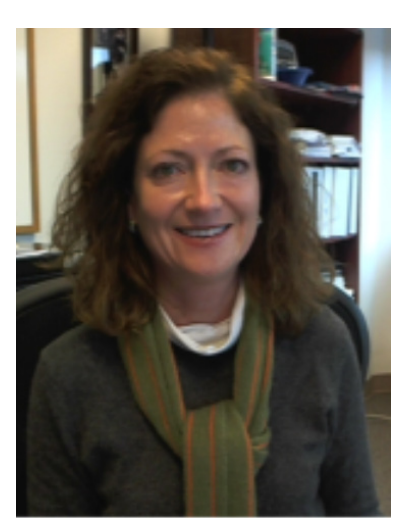

Carolyn A. Haug, Ph.D., is Executive Director of Accreditation and Program Effectiveness in the School of Education and Human Development at the University of Colorado Denver. She teaches program evaluation, measurement, and statistics in the Research and Evaluation Methodology program. Her research interests include teacher preparation, educator effectiveness, and student achievement. She has served as Director of Assessment for the Colorado Department of Education and Director of School Improvement and Accountability for the Adams County 50 School District, where she provided leadership in areas of assessment, school improvement planning, program evaluation and accountability, both statewide and at a local school district level. Dr. Haug has made numerous presentations at regional, national, and international conferences. 